\title{
Profile of patients with Fournier's gangrene and their clinical evolution
}

\section{Perfil dos pacientes com gangrena de Fournier e sua evolução clínica}

Dioney Rafael dos-Santos'; Ulisses luiz Tasca Roman'; André Pereira Westphalen, tCBC-PR; Kel Lovison²; Fernando Antonio C. SPEnCer Neto, TCBC-PR

A B S T R A C T

Objective: to analyze the profile of patients with Fournier's gangrene treated in a public tertiary hospital in western Paraná State. Methods: we conducted a cross-sectional, retrospective and descriptive study of patients with Fournier's gangrene treated between January 2012 and November 2016. Results: there were 40 patients with Fournier's gangrene treated in the period, 29 (72.5\%) men and 11 (27.5\%) women. The mean age was $51.7 \pm 16.3$ years. The mean time of disease progression, from the initial symptom to hospitalization, was $10.5 \pm 1.2$ days. All patients had clinical signs such as pain, bulging, erythema, among others, and 38 (95\%) had associated comorbidities, the most common being type 2 diabetes mellitus and systemic arterial hypertension. The majority (30 patients - 75\%) had perianal abscess as the probable etiology. All patients were submitted to antibiotic therapy and surgical treatment, with a mean of $1.8 \pm 1.1$ surgeries per patient. Nine (22.5\%) patients died. There was a strong correlation between the presence of sepsis on admission and mortality. Conclusion: Fournier's gangrene patients in this series had a long disease duration and a high prevalence of comorbidities, with a high mortality rate.

Keywords: Fournier Gangrene. Fasciitis, Necrotizing lepidemiology.

\section{INTRODUCTION}

$F_{s}^{\circ}$ ournier's Gangrene (FG) is a severe infectious disease of soft tissues, of fast progression, that affects the genital region and adjacent areas, characterized by intense tissue destruction, involving the subcutaneous and the fascia. This is a necrotizing fasciitis of the perineal region, also known as scrotal gangrene, synergistic necrotizing cellulitis, synergic gangrene, idiopathic gangrene and fulminant gangrene ${ }^{1,2}$. If not treated early, it can progress to sepsis and multiple organ failure ${ }^{3,4}$. Thus, early diagnosis along with appropriate and aggressive treatment are determinant factors in patients' prognosis. It occurs predominantly in males, between the third and sixth decades of life, with associated comorbidities such as renal and hepatic diseases, immunosuppression, acquired human immunodeficiency syndrome (AIDS), chronic diseases such as diabetes mellitus (DM), malnutrition, among others ${ }^{5,6}$. It displays high mortality rates, ranging from 13 to $30.8 \%$ in Brazil ${ }^{1,6,7}$. It represents a public health problem, considering its incidence, prevalence, mortality and the high costs of treatment and rehabilitation ${ }^{8}$.

In view of the severity and scarcity of data of the population that presents FG in Brazil, we sought to analyze the profile of the patients, their treatment and clinical evolution in a university hospital in western Paraná State.

\section{METHODS}

This research project was approved by the Ethics Committee of the State University of Western Paraná (UNIOESTE) on the campus of Cascavel/PR under the number 56997516.1.0000.0107. This is a crosssectional, retrospective and descriptive study based on analysis of physical and electronic records of FG patients treated at the University Hospital of Western Paraná HUOP/Cascavel - PR, from January 2012 to November 2016.

We included patients diagnosed with FG

1 - State University of Western Paraná, Cascavel, PR, Brazil. 2 - University of São Paulo, Ribeirão Preto, SP, Brazil. 
hospitalized at HUOP from January 2012 to November 2016 and over 18 years of age. We inputted data from physical and electronic records in a data collection form with information on demography, clinical and laboratory presentation, treatment instituted, evolution, complications and mortality.

We tested numerical variables for normality with the Shapiro-Wilk test and, since they displayed normal distribution, we presented them in mean and standard deviation. For the proposed correlations according to the objective of the study, we used the Pearson R test, 0.9 (positive or negative) being considered a very strong correlation, 0.7 to 0.9 , a strong correlation, and 0.5 to 0.7 , a moderate correlation. For the qualitative variables, we performed frequency distributions and presented them in absolute numbers and percentage. The software used the was SPSS ${ }^{2}$ Version 22.0. The information obtained from the medical records was presented through tables.

\section{RESULTS}

The sample consisted of 40 patients, 29 (72.5\%) males and 11 (27.5\%) females. The mean age was $51.7 \pm 16.3$ years. The mean length of hospital stay was $19.6 \pm 14.7$ days. Table 1 shows the main clinical signs.

Table 1. Main clinical signs in patients with FG.

\begin{tabular}{lc}
\hline \multicolumn{1}{c}{ Main clinical signs } & Number of patients (\%) \\
\hline Pain & $26(65 \%)$ \\
Bulging & $26(65 \%)$ \\
Erythema & $14(35 \%)$ \\
Cellulitis & $10(25 \%)$ \\
Sepsis & $9(22.5 \%)$ \\
Purulent collection & $9(22.5 \%)$ \\
Hyperemia & $7(17.5 \%)$ \\
Fever & $6(15 \%)$ \\
Tissue necrosis & $5(12.5 \%)$ \\
\hline
\end{tabular}

The mean time of disease progression, from the initial symptom to the hospitalization, was $10.5 \pm 1.2$ days, and nine patients (22.5\%) presented signs of sepsis at admission. Table 2 describes the main comorbidities. Only two patients did not report comorbidities.

Table 2. Major comorbidities in patients with FG.

\begin{tabular}{lc}
\hline \multicolumn{1}{c}{ Major comorbidities } & Number of patients (\%) \\
\hline Diabetes mellitus type II & $28(70 \%)$ \\
Arterial hypertension & $14(35 \%)$ \\
Heart disease & $6(15 \%)$ \\
Dyslipidemia & $3(7.5 \%)$ \\
Obesity & $3(7.5 \%)$ \\
Prostate disease & $2(5 \%)$ \\
Stenosis of urethra & $1(2.5 \%)$ \\
Hypothyroidism & $1(2.5 \%)$ \\
\hline
\end{tabular}

The probable etiology of FG was identified in all patients. Thirty (75\%) individuals had history and examination compatible with perianal abscess, four $(10 \%)$ trauma, three $(7.5 \%)$ perineal surgeries, two (5\%) urological diseases and one (2.5\%) animal bite.

All patients underwent antibiotic therapy and surgical debridement, in addition to concomitant treatment of comorbidities. We performed 72 surgical procedures, with a mean of $1.8 \pm 1.1$ procedures per patient. Of these, four patients (10\%) underwent colostomy to control fecal contamination and two (5\%) were submitted to cystostomy. In seven (17.5\%) patients, reconstruction surgeries were performed in the same hospitalization, after infection control.

Eight (20\%) patients remained hospitalized at the Intensive Care Unit (ICU). Nine (22.5\%) patients died. All had signs and symptoms of sepsis on admission $\left(r=0.93^{* *}\right)$. The remaining patients were discharged and were followed up at the HUOP outpatient clinic.

There was no correlation between sepsis presence at admission with time of disease evolution, age or presence of comorbidities. There was no correlation between diabetes and the presence of perianal abscess as a probable FG etiology. Table 3 shows the correlation between age, disease duration, comorbidities, ICU stay, perianal abscess as etiology and number of surgeries per patient with mortality. 
Table 3. Factors associated with FG mortality.

\begin{tabular}{lc}
\hline \multicolumn{1}{c}{ Correlations } & Mortality $(r)$ \\
\hline Age (years) & 0.16 \\
Disease evolution time (days) & 0.05 \\
Presence of comorbidities & -0.06 \\
Permanence in ICU & $0.57 *$ \\
Etiology: perianal abscess & -0.05 \\
Number of surgeries per patient & 0.30 \\
Sepsis admission & $0.93 * *$ \\
\hline
\end{tabular}

* Moderate Correlation; * * Strong correlation.

\section{DISCUSSION}

This study showed that all patients had local symptoms, associated comorbidities, long disease time before hospital admission and perianal abscess as the most common etiology. Knowledge of these factors may lead to earlier recognition of patients at risk, with an earlier diagnosis and reduction of associated morbidity and mortality.

FG is a necrotizing fasciitis that originates in the perineal region and can extend to the abdominal and thoracic wall. It can originate in the scrotum and penis in men, and in the vulva and in the groin in women ${ }^{9,10}$. It can also be associated with injuries, burns, abrasions, lacerations, bruises, animal bites, insect bites, subcutaneous and intravenous injections ${ }^{2}$. In our study, the FG etiology was predominantly associated with perianal abscess and with late or inadequate treatment. It is possible that early diagnosis, associated with an immediate surgical approach, could prevent some of these patients from progressing to FG.

In Brazil, the disease has a high prevalence in the male gender (10:1), but can also affect women and children ${ }^{6,11}$. It can affect all age groups, with an average around 50 years $^{12}$. In this study, $72.5 \%$ were males and $27.5 \%$ females, and in both genders, the mean age was 51 years.

With regard to its pathophysiology, bacterial infection leads to an obliterating endarteritis, followed by ischemia and thrombosis of the subcutaneous vessels, resulting in necrosis of the skin and impairment of the underlying fascia ${ }^{13,14}$. According to Santos², signs and symptoms such as local discomfort with painful sensation, elevated fever, malaise, sweating, edema apparently without injury, erythema and blistering can be found, corroborating the findings of the present study.

For clinical treatment, broad-spectrum antibiotics are used, covering gram-positive and gramnegative aerobic microorganisms, as well as anaerobes. The surgical procedure is indispensable ${ }^{2,15}$ and consists of extensive debridement of devitalized tissues, often demanding multiple reassessments. Patients not submitted to this procedure have a mortality rate of $100 \%^{1,16}$. All patients underwent clinical treatment with antibiotic therapy and surgical debridement as the initial treatment line.

In a study performed by Dornelas et al. ${ }^{1}$, reconstructive procedure was used in 23 patients, with simple and efficient techniques for each case or area, after effective infection control. Thus, small tissue losses were treated with border-to-edge suture or autogenous skin grafting. In our study, seven (17.5\%) patients underwent reconstructive surgery, mainly by primary repair, aiming at reducing the raw surface, facilitating dressings and early discharge. Since we have observed no adverse effects in the reconstructive surgeries, we have considered it in our service as part of the therapeutic flowchart of these patients, although there is a lack of definitive evidence of benefit.

In this study, the mean hospitalization time was over 19 days and $22.5 \%$ of the patients died. There was a strong correlation between sepsis on admission and mortality. Despite all the current therapeutic advances, FG continues to present prolonged hospitalization and high mortality rates ${ }^{17,18}$.

We could verify that the majority of patients diagnosed with FG treated in a tertiary public service of Western Paraná have late diagnosis and comorbidities, particularly type-II diabetes, with perianal abscess as an etiological factor. These patients had long hospitalization and high mortality. These data suggest the need for improvements in the emergency services, for the early diagnosis and treatment of the disease and to reduce its morbidity and mortality. 


\title{
R E S U M O
}

\begin{abstract}
Objetivo: analisar o perfil dos pacientes com gangrena de Fournier tratados em um hospital público terciário do oeste do Paraná. Métodos: estudo transversal, retrospectivo e descritivo de pacientes portadores de gangrena de Fournier atendidos no período de janeiro de 2012 a novembro de 2016. Resultados: foram tratados 40 pacientes com gangrena de Fournier no período: 29 (72,5\%)

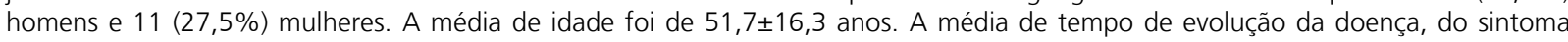
inicial até a internação, foi de 10,5 $\pm 1,2$ dias. Todos os pacientes apresentaram algum sinal clínico como dor, abaulamento, eritema, entre outros, e 38 (95\%) tinham comorbidades associadas, sendo as mais comuns diabetes mellitus tipo 2 e hipertensão arterial sistêmica. A maioria (30 pacientes - 75\%) apresentava como etiologia provável abscesso perianal. Todos os pacientes foram submetidos

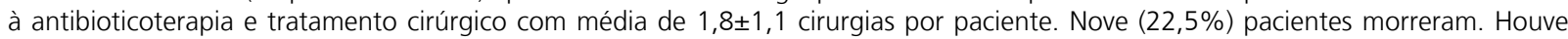
forte correlação entre a presença de sepse na admissão e mortalidade. Conclusão: pacientes portadores de gangrena de Fournier, nesta casuística, apresentavam longo tempo de doença e elevada prevalência de comorbidades com alto índice de mortalidade.
\end{abstract}

Descritores: Gangrena de Fournier. Fasciíte Necrosante/epidemiologia.

\section{REFERENCES}

1. Dornelas MT, Correa MPD, Barra FML, Corrêa LD, Silva EC, Dornelas GV, et al. Fournier's syndrome: a 10-year evaluation study. Rev Bras Cir Plást. 2012;27(4):600-4.

2. Santos EI, Vale ALVV, Reis ICPM, Neves PB, Pontes CM, Camara SGC. Brazilian scientific evidence on Fournier's gangrene. Rev Rene. 2014;15(6):1047-55.

3. Ramirez B, Cavalheiro CS, Campioni FC, Solla MF, Franco RL, Minata MK. Síndrome de Fournier. Rev Fac Ciênc Med Sorocaba. 2014;16 Supl:1-6.

4. Ward L, Eisenson D, Fils JL. Fournier's gangrene of the penis in a 12-year-old patient secondary to phimosis. $R$ I Med J. 2016;99(12):45-6.

5. Rocha DM, Bezerra SMG, Nogueira LT, Viana MCBR, Benício CDAV, Santos RR, et al. Scientific evidences on therapeutic methods in treatment of Fournier's gangrene. Int Arch Med. 2016;9(251):1-9.

6. Benjelloun el B, Souiki T, Yakla N, Ousaddean A, Mazaz $K$, Louchi $A$, et al. Fournier's gangrene: our experience with 50 patients and analysis of factors affecting mortality. World J Emerg Surg. 2013;8(1):13.

7. Corrêa Neto IJF, Sia ON, Rolim AS, Souza RFL, Watté $\mathrm{HH}$, Robles L. Clinical outcomes of Fournier's gangrene from a tertiary. J Coloproctol (Rio J.). 2012;32(4):40710.

8. Sroczyński M, Sebastian M, Rudinicki J, Sebastian S, Agrawal AK. A complex approach to the treatment of Fournier's gangrene. Adv Clin Exp Med. 2013;22(1):407-10.

9. Sorensen MD, Krieger JN. Fournier's gangrene: epidemiology and outcomes in the general US population. Urol Int. 2016;9(3)7:249-59.

10. Rocha ST, Castelan Filho JB, Petry MS, Bernardi RM, Bueno GB, Warmling CZ. Experiência inicial da terapia hiperbárica na síndrome de Fournier em um hospital de referência no sul catarinense. ACM Arq Catarin Med. 2012;41(4):71-6.

11. Abreu RAA, Leal Filho JMM, Corrêa $M$, Coimbra RAA, Figueiras ALM, Speranzini MB. [Fournier's gangrene: study of 32 patients - from diagnosis to reconstruction]. GED Gastroenterol Endosc Dig. 2014;33(2):45-51. Portuguese.

12. 12.Safioleas M, Stamatakos M, Mouzopoulos G, Diaba A, Kontonzoglou K, Papachirstodoulou A. Fournier's gangrene: exists and it is still lethal. Int Urol Nephrol. 2006;38(3-4):653-7.

13. Shyam DC, Rapsang AM. Founier's gangrene. Surgeon. 2013;11(4):222-32.

14. Roje Z, Matik D, Lindrenjak D, Dokuzovic S, Vardovic J. Necrotizing fasciitis: literature review of contemporary strategies for diagnosing and management with three case reports: torso, abdominal wall, upper and lower limbs. World J Emerg Surg. 2011;6(1):46.

15. Kaufmann JA, Ramponi D. Recognition of risk factors and prognostic indicators in Fournier's gangrene. Crit Care Nurs Q. 2015;38(2):143-53.

16. Eke N. Fournier's gangrene: a review of 1726 cases. Br J Surg. 2000;87(3):718-28.

17. Torremadé Barreda J, Millán Scheiding M, Suárez Fernández C, Cuadrado Campaña JM, Rodríguez Aguilera J, Franco Miranda E, et al. Gangrena de 
Fournier. Estudio retrospectivo de 41 casos. Cir Esp. 2010;87(4):218-23.

18. Candelária PAP, Klug WA, Capelhuchnik P, Fang CB. Síndrome de Fournier: análise dos fatores de mortalidade. Rev Bras Colo-proctol. 2009;29(2):197-

202.

Received in: 17/08/2017

Accepted for publication: 05/10/2017

Conflict of interest: none.

Source of funding: none.

\section{Mailing address:}

Djoney Rafael dos-Santos

E-mail: djoneysantos@hotmail.com /

djoney.com@gmail.com

\section{(cc) BY}

